Article

\title{
Farmers' Attitudes Towards the Use of Biomass as Renewable Energy-A Case Study from Southeastern Europe
}

\author{
Prespa Ymeri ${ }^{1} \mathbb{D}$, Csaba Gyuricza ${ }^{2, *}$ and Csaba Fogarassy ${ }^{3, *(\mathbb{D}}$ \\ 1 Doctoral School of Management and Business Administration, Szent Istvan University, Pater Karoly 1, \\ 2010 Gödöllő, Hungary; ymeri.prespa@phd.uni-szie.hu \\ 2 National Agricultural Research and Innovation Centre, Institute of Crop Production, Szent Istvan University, \\ Szent-Györgyi Albert utca 4, 2100 Gödöllő, Hungary \\ 3 Climate Change Economics Research Centre, Szent Istvan University, Pater Karoly 1, 2100 Gödöllő, Hungary \\ * Correspondence: gyuricza.csaba@mkk.szie.hu (C.G.); fogarassy.csaba@gtk.szie.hu (C.F.)
}

Received: 26 April 2020; Accepted: 11 May 2020; Published: 14 May 2020

check for updates

\begin{abstract}
Among the renewable energy sources, increasing the use of biomass (agricultural by-products) could be important from both an environmental and a climate protection perspective, but in many cases this is not a part of the current practice. Especially in developing countries, a large amount of agricultural waste suitable for energy use remains unused, remaining on the arable land or being burned in the field. Complicating matters is the fact that some countries have significant fossil energy reserves. This is also the case in Kosovo, which has the largest reserves of coal reserves (lignite) in southeastern Europe. An important question is how polluting and non-climate-friendly fossil fuels are to be replaced when they are available cheaply and in large quantities. The function of the political and economic models used in Europe has local specificity. It is not possible to copy the good solutions introduced by each country because of differences in the economic systems and farmers. Previous research has paid little attention to the producer conditions for available waste biomass sales. Studies have not examined the sales attitudes of farmers, or under what conditions they are willing to sell a larger proportion of the straw produced-of course, in such a way that they also meet the needs of animal husbandry, nutrients, and carbon supply. Using binary logistics regression and descriptive statistics not yet used in previous research, we analyzed the factors that influence farmers' willingness to sell, sales barriers, and incentives. According to the respondents, the biggest barriers to selling straw are the lack of a market (74.1\%) and baling machines $(50.9 \%)$, while the main incentives may be a good price $(75 \%)$ and a guaranteed contract $(67.8 \%)$. The farmers surveyed believe that, in a safe market, with a multiyear contractual agreement, they would sell more than half of their straw for biomass energy production. The use of straw in animal husbandry is declining due to the introduction of new technological solutions, so the use of straw for energy purposes is an increasingly topical issue in the rapidly developing southeastern European countries as well. Based on our research results, it can be stated that the majority of farmers are willing to sell more than $50 \%$ of the amount of straw produced for energy purposes if the business model and state regulations are appropriate.
\end{abstract}

Keywords: biomass for energy; open field burning; wheat straw; farmers' attitude; agricultural emission; binary logistic regression; willingness to sell; southeastern Europe

\section{Introduction}

As the EU's commitment to double its use of renewable energy by 2020 will boost demand for biomass, the renewable energy market is likely to become more important. The support from EU 
agricultural policy for the production and use of bioenergy in rural areas has increased as reducing the impact of renewable energy and climate change are priorities [1,2]. It is understandable that the growing global demand for energy, food, feed, and raw materials is putting pressure on arable land and specific social groups. Hence, the EU calls for the sustainable production of biofuels (a positive energy balance). The primary objective is to ensure that when Member States use biomass for energy purposes in the EU, it does not harm the environment, endanger efforts to mitigate climate change, or have negative social impacts [3]. Kosovo [4] has a limited energy supply, but it has the largest reserves of coal (lignite) in southeastern Europe, which are also the second-largest in Europe and fifth-largest in the world [5] and are used as the main source of energy production (97\%) [6]. Of the total gas emissions that are produced in the country, the energy sector makes the greatest contribution of around $82 \%[7,8]$. Kosovo is not a member of the EU, but its Energy Strategy pays particular attention to adjusting its obligations under the Energy Community Treaty (EnCT) with regard to renewable energy sources. The most promising renewable energy sources are solar and biomass energy. Different studies state that emission rates can be decreased sustainably in the medium term if we integrate renewable energy (as an element of the circular economy) into the planning process [9,10]. According to Kashif et al. [11], the generation of renewable energy from crop residues will boost the local circular economy and create thousands of jobs in several sectors. Currently, environmental and social values are a major requirement for modern businesses, and can lead to higher economic performance in several cases [12]. Kosovo is an agricultural country: arable land consists of around half of its territory, but most of the farms are characterized as family farms [13]. Grain occupies more than half of the arable land and areas cultivated with wheat have the highest share; however, self-sufficiency is relatively low, while residues of agriculture in Kosovo are not yet used. The development of integrated renewable energy production systems is imperative [14]. Gabrielle and Gagnaire [15] suggested the use of straw to replace fossil fuels in the production of bioenergy. Cereal straw is considered a potential source of abundant energy supply, estimated at $47 \times 1018 \mathrm{~J}$ worldwide. Residues that are generated from agriculture and forestry operations can guarantee a potential source of bioenergy; this source is seen as particularly attractive as it is not related to land use change issues and is estimated to be of low cost as a by-product of existing operations [16]. By selling the straw, farmers can gain additional income and increase the production of wheat as well [17]. Currently, the EU has no general policy on the removal of straw for heating purposes [18]. The costs and difficulties of long-term storage and transport are seen as obstacles to the use of straw for energy purposes [19]. Cereal straw is usually advertised on the local market, through auctions or private sales, and sold as a baled crop, a "sold-in-swath", or a standing crop. These bioenergy functions are likely to require contractual arrangements with farmers, perhaps similar to the raw materials used for cereals; there is at present no information on the characterization of these contracts, which farmers would find acceptable, nor on the amount of straw available [18]. In the literature, we find different factors that determine the availability of cereal straw like: biomass field, cultivated varieties, straw harvesting and the ratio of straw to cereal biomass [20], crop rotation, farming practices (e.g., soil cultivation), climate, and soil physical properties [21]. Currently, in Kosovo, straw removed from fields is mainly used in animal husbandry for feeding and bedding [22]. Straw that has not been removed is usually burned in the fields after the harvest [23]. It is worth noting that, in England and Wales, up to $41 \%$ of wheat straw was burned on arable land before the ban [24], while in Egypt this figure was $52 \%$ [25]. The literature that offers us a general methodology to evaluate crop harvesting and procurement based on sustainability criteria (maintaining soil fertility, nutrients, and carbon content; and preventing other uses) is limited [21]. Therefore, our two research questions are: (1) Why has the once-widespread practice of burning straw changed in countries where it is no longer part of everyday practice? and (2) What changes in the market or regulatory conditions are required to avoid this polluting production practice? 


\section{The Quantity of Straw Available}

Palmieri et al. [26] found that the incorporation of straw proved to be the best environmental practice but, in their current situation, concluded that selling straw on the local market for energy production was a better solution. Aggregated results show that the use of straw biomass for energy purposes is better than that of coal [27]. According to Dees et al. [28], approximately 50\% of straw can be removed without reducing the carbon content of the soil, although the level of removal varies greatly from region to region. In the Globiom report, a study commissioned by the EU executive focusing on "indirect land-use change" (ILUC) distinguishes between sustainable and unsustainable plant residues. If the harvest of wheat straw is limited to a sustainable removal rate of $33-50 \%$, no yield-reducing effects occur [29] and consequently, the effect of ILUC is zero. According to Wieser et al. [30], approximately $27 \%$ of straw can be classified as sustainable straw, and the energy use of this straw can result in a 73.3-92.3\% reduction in greenhouse gas emissions compared to fossil numbers. Jinming and Overend [31] suggested a collectable amount of around $60 \%$. Other studies assume that, of the total amount of agricultural residues available, approximately $25 \%$ can be recovered for bioenergy production and the remaining straw stubble is returned to the soil [32,33]. In terms of energy use, various measurements of potential straw were analyzed, most of them related to the theoretical potential of crop residues based on the area or production of each crop cultivated and the average residue yields (usually available from regional or national statistical offices as well as from the literature or from referenced local trials) [34-37]; for example, in the analysis of Scarlat and Monforti et al. [38,39], areas and residual product ratio data were taken from the literature and government data. According to Glithero et al. [20], however, the difference in levels observed in England for the three crops (wheat) was greater than previously expected for residue and grain ratios; the study estimated the yield based on the area of straw and the number of straw bales. In a study by Marks-Bielska et al. [40], potential straw was calculated from statistics on plant structure and livestock. In a study by Zhang et al. [41], the amount of residue available for use was calculated based on certain parameters of each crop, which were recommended from the literature. Chinnici et al. used coefficient availability, while Cai et al. calculated the quantities that can be collected after taking into consideration the quantities that must be left to maintain soil quality as well as the ratio of grass to grain $[42,43]$. However, when different authors took into account the willingness of farmers to sell straw, the availability of straw changed. Again, Glithero et al. [18] estimated straw yields on the basis of straw use area, number of straw bales, and willingness to sell the straw. Giannoccaro [44] took data from farmers on a range of topics into consideration, including farming practices, the farm profile, current straw uses, sociodemographic data, and farmers' willingness to deal with energy market and sell their straw. According to this author, the assessment of biomass availability has generally been focused on technical and agronomic feasibility, while in the economics of biomass it is possible to apply another method to calculate the availability of biomass. This method takes into consideration the willingness of farmers to supply [45-47]. A comparison between this approach and the convention alone could lead to new interdisciplinary collaborations, and this type of data could be used as a basis for further studies. According to Gaus [48], farmers' decision-making determines the amount of straw available on the market. The straw producers in his study sample were willing to sell on average $45 \%$ of their annual straw production, and with a higher price additional straw would be sold. In the study by Glithero [18], in England farmers were willing to sell $43 \%$ of their total wheat straw; however, this percentage changed according to different parts of England and the variation was from $33.21 \%$ to $67.35 \%$. The main aims of this study are to estimate the amount of straw that farmers are willing to sell for bioenergy purposes, to determine the socioeconomic factors that impact farmers' willingness to sell straw by separating them in two groups: farmers who are willing to sell less straw and farmers with higher amount of selling (less than 50\% and more than 50\%), and to analyze the potential barriers to and incentives toward selling straw for bioenergy. Thus, the study applied a binary logistic regression to find out which variables are significant and shaped the willingness to sell the straw. 


\section{Methodology}

The area does not yet have any official plan on transportation cost and distance for straw as bioenergy. The municipalities were selected throughout regions at a distance of up to $70 \mathrm{~km}$ from an energy plant site, similar to the distance used in the study of Giannoccaro [44]. Kosovo is divided into seven regions and 38 municipalities [49]. Our sample was chosen based on the willingness of farmers to cooperate; it consisted of six regions and four municipalities within the regions. The sample sizes of the six regions were: 58; 56; 50; 20; 11 ; and 11 (number of questionnaires distributed). There are only two power plants, Kosova A and Kosova B in the capital city, that produce electricity from coal lignite; we can also consider the role that pellet producers can have in terms of straw distribution. Due to the absence of knowledge on using the Internet among farmers, the questionnaires were filled out by hand. The data were collected by the researchers through personal interviews, during personal visits to the respondents' homes or workplaces, and in one of the mill buildings. Before beginning the interview, each respondent was given a brief idea of the purpose of the study (for academic research). The questionnaire contained questions regarding socioeconomic factors, the farm profile, the practice of using straw, and their willingness to sell the straw. The collection of data was done during the period May-October 2019. Data were collected by applying a semistructured questionnaire whereby farmers were also allowed to express their concerns. The questionnaires were pretested with a sample size of 10. This was due to the absence of knowledge on renewable energy sources and the limited use of online questionnaires among farmers. They were distributed to 230 farmers in the country and 206 farmers responded (response rate: $89.57 \%$ ). We consider that the sample in the study is statistically representative at the national level because of the data collection methods used. The sample adequacy test showed that the sample chosen for the study is adequate at a $95 \%$ confidence level with a margin of error of $6.7 \%$.

\section{Data Analysis}

Data were analyzed by using Statistical Package for the Social Sciences (SPSS 19); descriptive analyses were conducted for variables as well as binary logistic regression to find the significant factors influencing the percentage of straw that farmers are willing to sell to power plants. Binary logistic regression is also known as a logistic model or logit model, which analyzes the relationship between multiple independent variables and a categorical dependent variable, and evaluates the likelihood of occurrence of an event by fitting the suitable data to a logistic curve [50]; we find a similar analysis regarding the willingness of farmers in the study of Muriqi et al. [51]. Using this model, the factors ( $X$-independent variables) affecting the willingness to sell straw, and the results ( $Y$-dependent variables) could be measured. The formula used for the analysis is as follows:

$\mathrm{Y}=\mathrm{B}_{0}+\mathrm{B}_{1}$ Already sell the straw $+\mathrm{B}_{2}$ Soil Concerns $+\mathrm{B}_{3}$ Presence of animals $+\mathrm{B}_{4}$ Engagement in Agriculture $+B_{5}$ Age $+B_{6}$ Farm size with wheat $+B_{7}$ Farm type $+B_{8}$ Employment $+B_{9}$ Education + $\mathrm{B}_{10}$ Percentage of willing to sell corn $+\mathrm{B}_{11}$ Farm size with corn $+\mathrm{B}_{12}$ Family size + ui.

In order to meet the sustainability criteria, $50 \%$ of the straw is considered as the highest value that could be removed from the field and used for energy purposes. Thus, we separated the farmers into two groups: those who are willing to sell a sustainable amount of straw (less than or equal to 50\%) and those who engage in unsustainable practices (selling more than $51 \%$ ). The model is described as follows: The percentage of willingness to sell was involved as the binary dependent variable $((0)$ less than $50 \%$; (1) more than $50 \%$ ). Twelve variables were included in the model (Figure 1) using the Enter Method: I. Sell the straw on market ((0) not selling the straw; (1) already selling the straw); II. Soil concerns ((0) not incorporated; (1) incorporated into the soil); III. The presence of animals ((0) do not have animals; (1) have animals); IV. Engaged in agriculture ((0) part-time farmer; (1) full-time farmer); V. Age of the farmer: ((0) 20-40 years old; (1) $>41$ years old); VI. Farm size with wheat: based on hectares per farm ((0) 0.01-9.99 ha; (1) >10 ha) VII. Farm type ((0) wheat; (1) wheat and corn); VIII. Employment ((0) outside of agriculture; (1) agriculture); IX Education ((0) elementary/higher school; 
(1) university) X. Percentage willing to sell corn ((0) not planning to plant corn; (1) $<50 \%$; (2) $>50 \%$ ); XI. Farm size with corn ((0) 0-9.99 ha; (1)>10 ha). XII. Family size ((0) 1-9 members; (1) >10 members).

\section{Results}

The aspects of the use as animal feed and the use as a fuel were clear even without the questionnaire query. According to the literature, the sale of biomass for briquettes or pellets could be a future option. Opportunities will primarily be determined by the price of the new product.

In the Table 1 , we can see that around $96 \%$ of the farmers use wood for heating purposes; $87.6 \%$ use only wood, $7.7 \%$ use wood associated with coal, and $4.01 \%$ use pellets. From the total sample, $15.6 \%$ of farmers had only wheat with an average number of animals of 2.07 , while the other farmers who had more animals also had a higher area of corn cultivation, which means they are using corn and wheat in rotation.

Table 1. House heating methods.

\begin{tabular}{ccc}
\hline House Heating Methods & Mean \& S.D. & Number of Animals \\
\hline Pellets $(4.1 \%)$ & $3.13 \pm 0.69($ tons $)$ & \\
Wood $(87.6 \%)$ & $16.83 \pm 8.02\left(\mathrm{~m}^{3}\right)$ & \\
\hline Wood and coal $(7.7 \%)$ & $10.40 \pm 4.08\left(\mathrm{~m}^{3}\right)$ & \\
\cline { 2 - 3 } & $6.07 \pm 3.71($ tons $)$ & $2.07 \pm 2.76$ \\
\hline Farm size & $4.40 \pm 9(\mathrm{ha})$ & $7.81 \pm 14.76$ \\
\hline Wheat $(15.6 \%)$ & $6.41 \pm 17.32(\mathrm{ha})$ & \\
\hline Wheat and corn $(84.4 \%)$ & $4.49 \pm 9.15(\mathrm{ha})$ & \\
\cline { 2 - 3 }
\end{tabular}

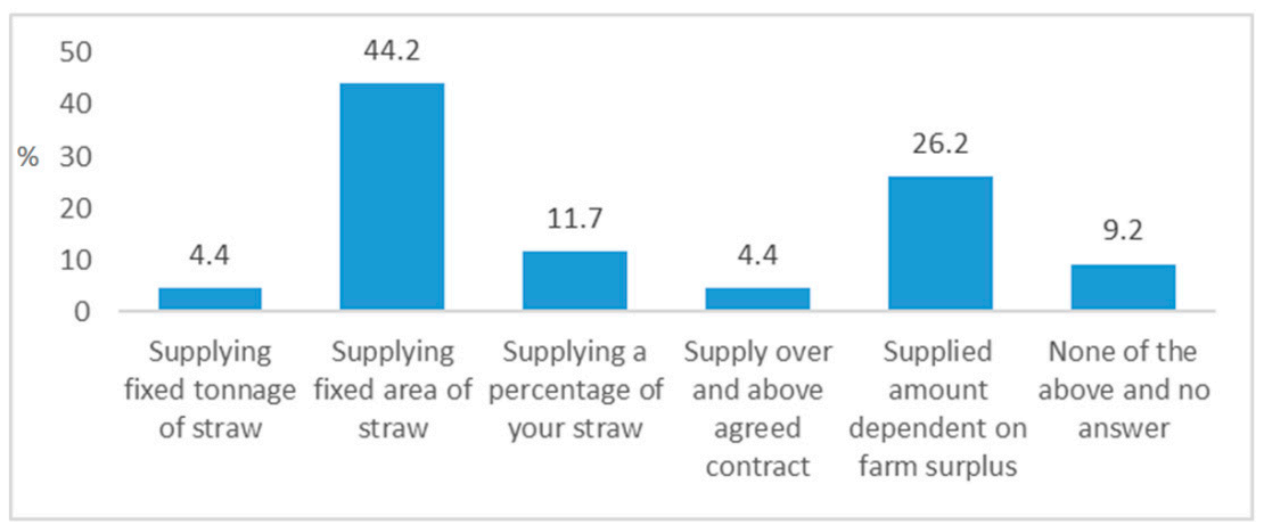

Figure 1. Quantity supply contract preferences (sample size: 206).

\subsection{Contract Volumes and Price Preferences}

The preferences of farmers regarding the quantity (Figure 1) and prices (Figure 2) of straw sold via contracts with a power plant are as follows: The highest frequency was for supplying a fixed area of straw, for a spot market price, while the second highest was for supplying an amount dependent on the farm surplus. As for price, the second most popular response was a fixed price. 


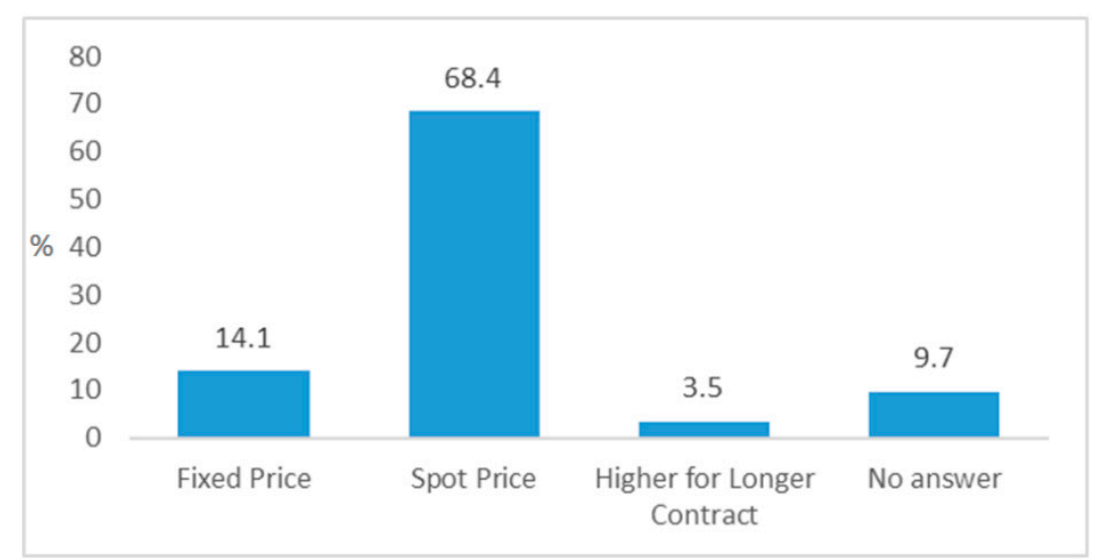

Figure 2. Price supply contract option preferences (sample size: 206).

\subsection{Reasons for not Baling Straw and Incentives to Encourage Baling}

When farmers were asked about their reasons for not baling/selling (including selling in swath) some or all of their straw (Figure 3), the most popular response was a lack of market interest and the second reason was a lack of machinery. These two reasons were also the most popular responses for corn. There were additional reasons for not baling but these were mentioned less often: the time of operation (i.e., delays in the establishment of the next crop), the perceived benefits of incorporation (soil structure/nutrients), concerns about contracts, and concerns about soil quality. When farmers were asked about factors that would motivate them to bale and sell their straw (Figure 4), the most popular response was a good price, followed by a guaranteed market and guaranteed price. Farmers were generally less interested in a fixed price, and some of them will not be encouraged by any of these reasons.

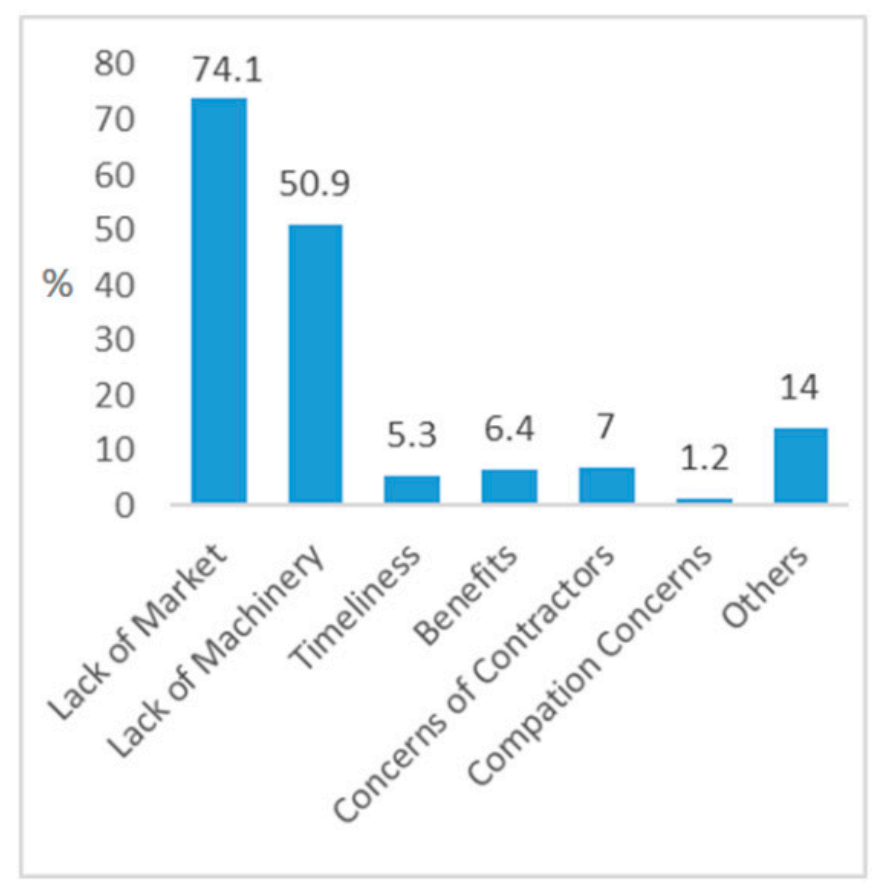

Figure 3. Reasons for not baling/selling straw (sample size: 206). 


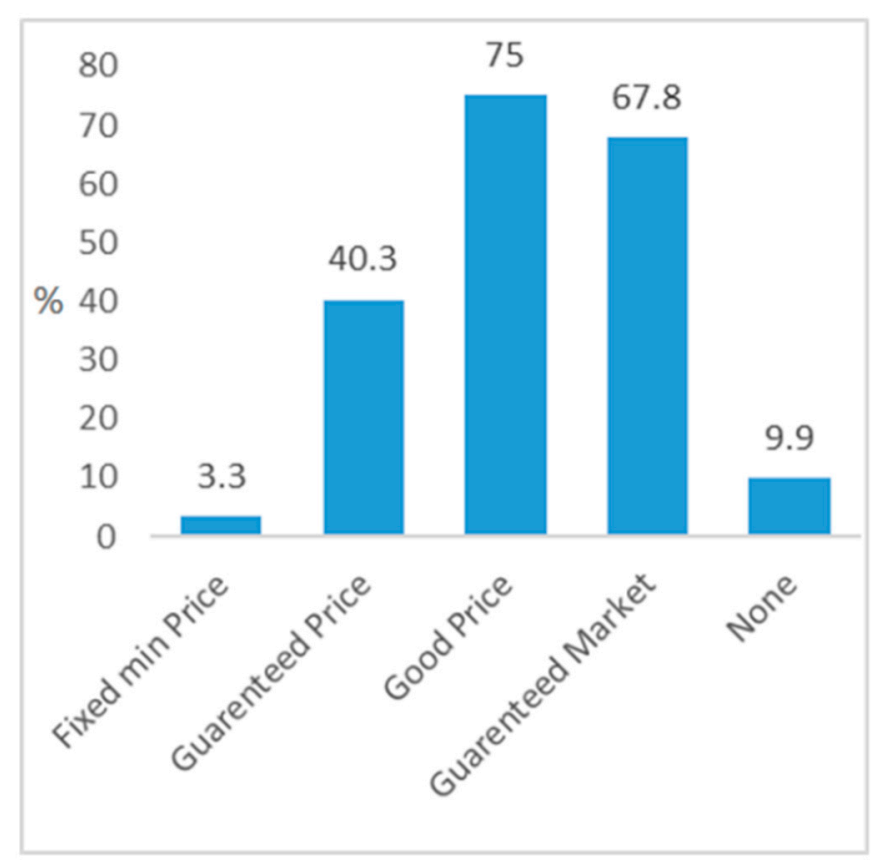

Figure 4. Incentives to encourage straw baling (sample size: 206).

Because most of the farmers had corn, we asked them about the use of corn straw (Figure 5). Farmers were allowed to respond with more than one answer. On the actual use of corn straw, the most popular answer was for animal feed, where stalks were $49.5 \%$ and cobs were $39.9 \%$; this difference could be because some of the farmers used special machinery that grates the stalks and cobs together and uses the result as animal feed, while farmers who did not use this machinery used only stalks as animal feed and the other farmers left it on the soil (grated or in its basic form). There are cases where farmers used the cobs for heating purposes (29.3\%), and also where they gave it away for free. Morissette et al. [52] explained the potential for heat production using baled corn stover as a complementary energy source to wheat straw.

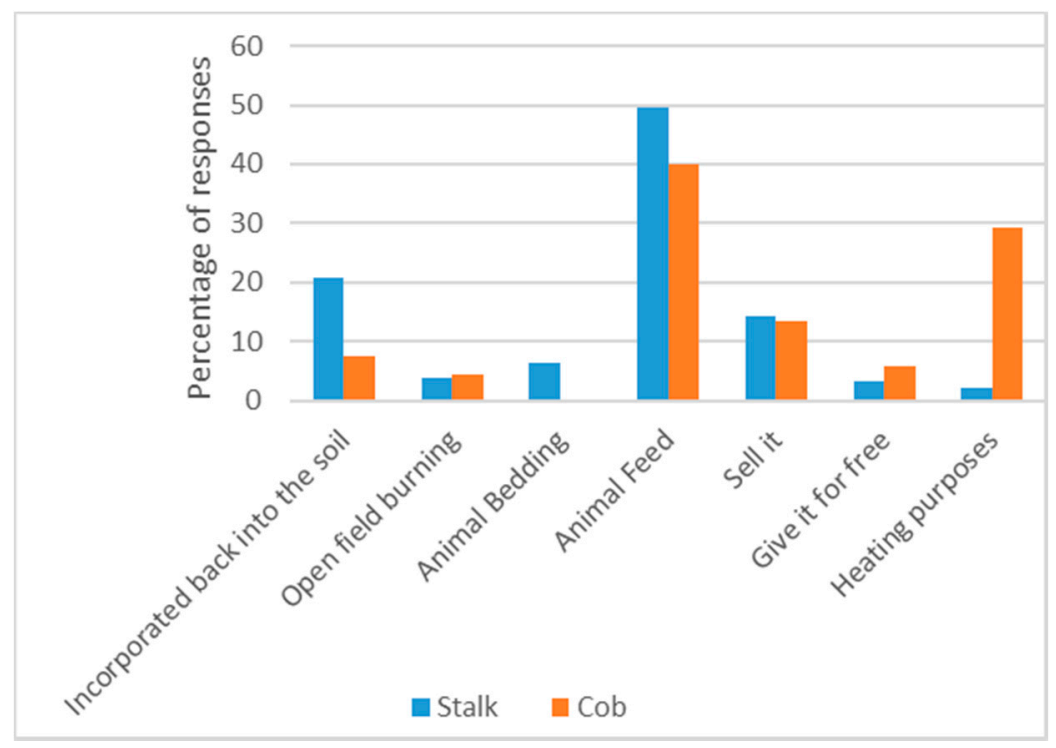

Figure 5. Actual use of stalks and cobs (sample size: 206). 


\subsection{Length of Supply and Contract}

Farmers were asked about the length of time (in years) (Figure 6) they would prefer to consecutively supply straw to a bioenergy plant, and also the maximum contract length that would be acceptable to them. Almost all of the farmers gave the same response for both, so we combined them into one question. The most popular contract lengths were 10 years $(39.4 \%), 15$ years $(20 \%)$, and three years $(7.2 \%)$. Note that while contract lengths of 15 years or less were most popular, none of the farmers rated a contract of 12,13 , or 14 years, while $6.7 \%$ of farmers preferred a five-year contract. The minimum price for which farmers were willing to sell the straw was $€ 0.50 /$ bale (Figure 7); this was selected by $45.9 \%$ of all respondents, with $0.5 \%$ of farmers able to give it for free at a farm gate (if harvested by the one who receives it). The highest price was $€ 2 /$ bale; $28 \%$ of all respondents already sold straw, and of these $52 \%$ sold it for a price of $€ 0.5 / \mathrm{bale}$, which is the market price, while the highest price was $€ 1$ ( $16 \%$ of farmers). The other $71.6 \%$ did not sell at all. Additionally, one bale was equal to $15 \mathrm{~kg}$ straw and $90.7 \%$ of farmers from the sample would be willing to sell their wheat straw to a bioenergy plant, while $9.3 \%$ did not agree to sell it.

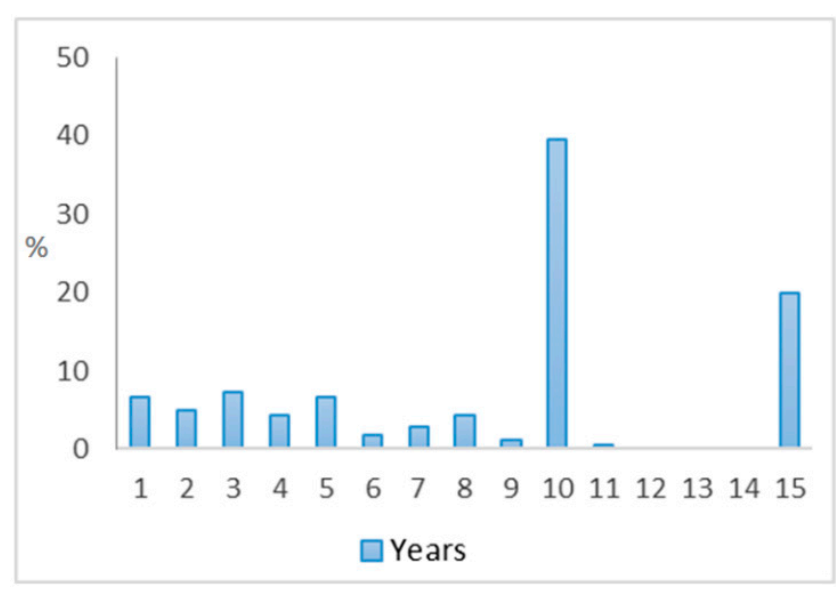

Figure 6. Maximum contract length supplying.

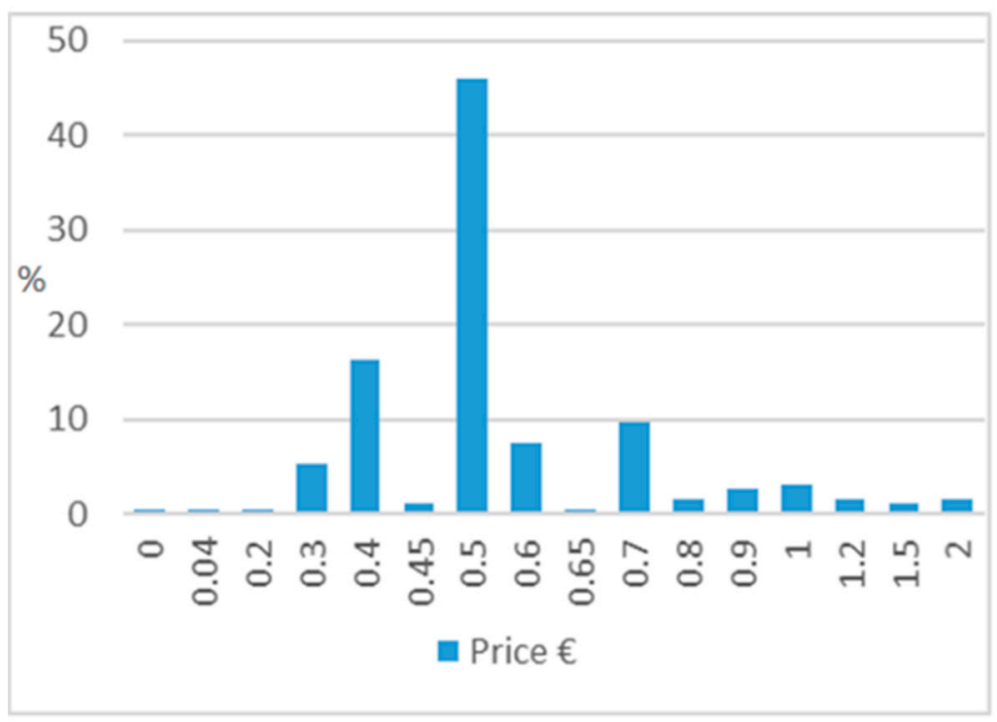

Figure 7. The preferred price of straw (sample size: 206).

From Table 2 we can see that around $66.72 \%$ of straw is used for animal farm needs with a little going into the soil; the other $33.38 \%$ is sold, given for free, or burned, while the willingness to sell it for energy purposes is around $65 \%$. The details are as follows: 20 respondents incorporated $20-50 \%$ of the 
straw, while 10 farmers incorporated the straw completely into the soil. The others did not incorporate the straw at all. Only two farmers declared that they burn $100 \%$ of the straw in the field, while the others did not burn it at all. However, this issue needs special attention, because the number of farmers who burn the straw is very low in our sample, while in reality the Ministry of Environment and Spatial Planning calls for farmers to not burn the straw as there is a risk of burning buildings or forest.

Table 2. Straw use practices in a sample size of 206 farmers.

\begin{tabular}{|c|c|c|c|c|c|c|c|}
\hline Percentage & Incorporated into Soil & Burn into Field & Bedding & Feed & Sell it & Give it for Free & Willingness to Sell \\
\hline 0 & 173 & 204 & 106 & 133 & 148 & 186 & 18 \\
\hline 10 & 1 & & & 1 & & & 3 \\
\hline 15 & & & & & 1 & & 1 \\
\hline 20 & 3 & & 1 & 2 & & & 9 \\
\hline 25 & 1 & & & 1 & & & \\
\hline 30 & 1 & & & 12 & 1 & & 11 \\
\hline 35 & 1 & & 1 & & & & \\
\hline 40 & & & & 1 & 1 & & 3 \\
\hline 45 & 1 & & & & & & \\
\hline 50 & 13 & & 35 & 39 & 15 & 1 & 48 \\
\hline 55 & & & 1 & & & & \\
\hline 60 & & & & 1 & 1 & & 11 \\
\hline 65 & & & 1 & & & & \\
\hline 70 & 1 & & 9 & 1 & 1 & & 5 \\
\hline 75 & 1 & & & 1 & & & 4 \\
\hline 80 & & & & 1 & 2 & 1 & 14 \\
\hline 85 & & & & 1 & & & \\
\hline 90 & & & 1 & & & & 7 \\
\hline 95 & & & & & & & \\
\hline 100 & 10 & 2 & 51 & 12 & 36 & 18 & 72 \\
\hline Mean (\%) & 9.73 & 0.97 & 37.60 & 19.39 & 22.94 & 9.37 & 64.73 \\
\hline
\end{tabular}

The bedding straw practice was applied by $48.5 \%$ of the farmers: 33 respondents use around $50 \%$ of the straw for bedding purposes, while 51 farmers use $100 \%$ of their straw for bedding. Furthermore, 56 farmers used around $50-100 \%$ of their straw for animal feed, while most of them (133) did not use it at all. From the total sample, 51 farmers were able to find a market for selling their straw $(50-100 \%)$, while the rest did not sell it at all. There were 20 farmers who give the straw for free in exchange for wheat harvest. Farmers were asked if they are willing to sell the straw for energy purposes. From the total sample, 18 did not agree to sell the straw, while the others were willing to sell it but a different amount or percentage. For example, 113 farmers were willing to sell more than $50 \%$ of their straw for energy purposes, which is not in accordance with the suggestions of authors [28] commissioned by the EU [29]. Of the rest of the respondents, 93 were willing to sell less than $50 \%$ of the straw. For this reason, we decided to separate the farmers into two groups and check different variables that had an influence on the willingness to sell the straw.

\subsection{Descriptive Data of Farmers}

Concerning the socioeconomic factors of willingness to sell straw, the results (Table 3) showed that most of the farms cultivated mixed cultures of wheat and corn; their average land size for wheat was 6.41 ha and for corn it was 4.49 ha, with the average number of animals being 7.81; on the other hand, a low number of farmers cultivated only wheat with an average land size of 4.40 ha and an average number of animals of 2.07. From the total sample, more than a quarter of farmers worked outside agriculture (including those employed in the public sector or private sector, self-employed in the nonagricultural sector, and other), while the others did not have any other work except agriculture. More than three-quarters of farmers had finished secondary school, and the rest had finished university. As for the land area devoted to wheat, most wheat farmers (89.3\%) had large-scale farms of 0.01-9.99 ha, while a minority had $>10$ ha. Almost the same true for corn: the majority of farmers $(92.7 \%)$ had 0.01-9.99 ha and only a few had $>10 \mathrm{ha}$. When farmers were asked if they incorporate the straw into the soil, most ( $84 \%$ ) declared that they do not incorporate the straw, while the others said the opposite. 
From the total sample, more than half of farmers (68\%) have animals, while the others have none. More than half $(69.4 \%)$ of the farmers were engaged in agriculture as a full-time occupation, while the others were part-time farmers.

Table 3. Farmers' basic characteristics.

\begin{tabular}{|c|c|c|c|c|}
\hline Factor & Code and Sort & Frequency & $\%$ & Mean and St. dev \\
\hline \multirow{2}{*}{ I. Farm type } & [0]. Wheat & 32 & $15.5 \%$ & $0.656 \pm 483$ \\
\hline & [1]. Wheat and Corn & 174 & $84.5 \%$ & $0.523 \pm 500$ \\
\hline \multirow{2}{*}{ II. Employment } & [0]. Outside of Agriculture & 68 & $33 \%$ & $0.5882 \pm 0.496$ \\
\hline & [1]. Agriculture & 138 & $67 \%$ & $0.5217 \pm 501$ \\
\hline \multirow{2}{*}{ III. Education } & [0]. Elementary/higher school & 166 & $80 \%$ & $0.5361 \pm 500$ \\
\hline & [1]. University & 40 & $19 \%$ & $0.575 \pm 500$ \\
\hline \multirow{2}{*}{ IV. Soil Concerns } & [0]. Not Incorporated & 173 & $84 \%$ & $0.503 \pm 501$ \\
\hline & [1]. Incorporated into the soil & 33 & $16 \%$ & $0.758 \pm 0.435$ \\
\hline \multirow{2}{*}{ V. Animals } & [0]. Don't have animals & 66 & $32 \%$ & $0.879 \pm 0.323$ \\
\hline & [1]. Have animals & 140 & $68 \%$ & $0.386 \pm 0.489$ \\
\hline \multirow{2}{*}{ VI. Engagement in agriculture } & [0]. Part-time farmer & 63 & $30.6 \%$ & $0.556 \pm 0.500$ \\
\hline & [1]. Full-time farmer & 143 & $69.4 \%$ & $0.539 \pm 0.500$ \\
\hline \multirow{2}{*}{ VII. Currently sell the straw } & [0]. Do not sell the straw & 148 & $71.8 \%$ & $0.487 \pm 0.501$ \\
\hline & [1]. Sell the straw & 58 & $28.2 \%$ & $0.690 \pm 0.467$ \\
\hline \multirow{2}{*}{ VIII. Age } & [0]. 20-40 years old & 70 & $34 \%$ & $0.571 \pm 0.498$ \\
\hline & [1]. $>\geq 41$ years old & 136 & $66 \%$ & $0.529 \pm 0.501$ \\
\hline \multirow{3}{*}{ IX. Percentage of corn } & [0]. Not planning to plant corn & 24 & $11.7 \%$ & $0.67 \pm 0.482$ \\
\hline & {$[1] .<50 \%$} & 76 & $36.9 \%$ & $0.08 \pm 0.360$ \\
\hline & {$[2] . \geq 51 \%$} & 106 & $51.5 \%$ & $0.86 \pm 0.350$ \\
\hline \multirow{2}{*}{$X$ Land area of wheat } & [0]. 0.01-9.99 & 184 & $89.3 \%$ & $0.544 \pm 0.500$ \\
\hline & {$[1] . \geq 10$} & 22 & $10.7 \%$ & $0.546 \pm 0.510$ \\
\hline \multirow{2}{*}{ XI. Land area of corn } & [0]. 0-9.99 ha & 191 & $92.7 \%$ & $0.55 \pm 498$ \\
\hline & {$[1] . \geq 10$ ha } & 15 & $7.3 \%$ & $0.47 \pm 516$ \\
\hline \multirow{2}{*}{ XII. Household size } & [0]. (1-9) & 154 & $74.8 \%$ & $0.533 \pm 0.500$ \\
\hline & [1]. $(\geq 10)$ & 52 & $25.2 \%$ & $0.577 \pm 0.499$ \\
\hline Dependent variable & [0]. $(<50 \%)$ & 93 & $45.1 \%$ & $33.07 \% \pm 20.01$ \\
\hline (Willingness to sell wheat straw) & [1]. $(\geq 51 \%]$ & 113 & $54.9 \%$ & $89.73 \% \pm 16.58$ \\
\hline
\end{tabular}

As for age, $34 \%$ of the farmers were $20-40$ years old, while the others were over 40 . When asked if they were willing to sell corn straw for energy purposes, $11.6 \%$ of the farmers declared that they are not planning to plant corn at all; $36.9 \%$ were willing to sell $<50 \%$ to power plants, and the other parts $(51.5 \%)$ were willing to sell more than $50 \%$. Around one-quarter of the farmers had more than nine family members, while the rest had households of 1-9 members (the average). Only $45.1 \%$ of farmers wanted to sell less than half of their straw, while the rest were willing to sell more than $50 \%$ of the straw. The average price for farmers who are willing to sell less than $50 \%$ was 0.59 ( $€ / 15-\mathrm{kg}$ bale), and for those who wanted to sell more than $50 \%$ of the straw the price was 0.56 ; however, this is not a significant difference $(p<0.05)$. Taking into consideration that the ratio of mass of fruits to mass of plants reported in wheat is 1:1, in 2017, of the 120,746 tons of wheat yield [14], 120,746 tons of straw were produced; considering that the percentage of willingness to sell the straw was $64.73 \%$, we calculate $78,158.89$ tons, and the average price is $€ 0.57 / 15-\mathrm{kg}$ bale. The price for a ton would be 38 euros, and in total farmers would generate 2,970,038 euros.

\subsection{Binary Logistic Regression}

Binary logistic regression was used to check significant factors influencing the willingness of farmers to sell their straw. The logistic regression model gave a statistically significant result of $\chi^{2}(9)=131.095, p<0.001$. This model explained between $47.1 \%$ (Cox and Snell $R^{2}$ ) and 63\% (Nagelkerke $R^{2}$ ) of the variance in percentage of willingness to sell the straw and correctly classified $85.9 \%$ of the cases. Additionally, we obtained an insignificant value for the goodness-of-fit test (Hosmer and Lemeshow) $\chi^{2}(8)=9.146, p>0.330$. Table 4 presents the logistic regression output of the factors determining the willingness to sell straw of farmers in Kosovo. 
Table 4. Binary logistic regression; factors affecting cooperation activity.

\begin{tabular}{cccccccc}
\hline Factors & B & S.E. & Wald & Df & Sig. & Exp(B) & R \\
\hline Already sell it & -1.034 & 0.521 & 3.940 & 1 & 0.047 & 0.356 & 0.083 \\
Incorporated into soil & 0.620 & 0.599 & 1.072 & 1 & 0.300 & 1.859 & - \\
Have cows & -3.535 & 0.662 & 28.479 & 1 & 0.000 & 0.029 & 0.306 \\
Full-time/part-time & -0.992 & 0.573 & 2.999 & 1 & 0.083 & 0.371 & 0.059 \\
Age & -0.463 & 0.444 & 1.088 & 1 & 0.297 & 0.629 & - \\
Wheat area & 0.162 & 0.830 & 0.038 & 1 & 0.846 & 1.175 & - \\
Corn area & -0.165 & 1.048 & 0.025 & 1 & 0.875 & 0.848 & - \\
Farm type & -3.316 & 0.801 & 17.120 & 1 & 0.000 & 0.036 & 0.231 \\
Family & 0.326 & 0.495 & 0.433 & 1 & 0.511 & 1.385 & - \\
Employment & 0.239 & 0.543 & 0.193 & 1 & 0.660 & 1.270 & - \\
Education & 0.024 & 0.592 & 0.002 & 1 & 0.968 & 1.024 & - \\
$\%$ Willingness to sell corn & 3.393 & 0.513 & 43.671 & 1 & 0.000 & 29.748 & 0.383 \\
Constant & 1.827 & 0.778 & 5.522 & 1 & 0.019 & 6.217 & 0.111 \\
\hline
\end{tabular}

-2log likelihood 152.537; Hosmer and Lemeshow $\left(\chi^{2}=9.146, \mathrm{df}=8, p=0.330\right) ;$ Pseudo R-squares (Cox and Snell $R^{2}=47.1 \%$; Nagelkerke $R^{2}=63 \%$ ); Overall percentage correctly predicted $=85.9 \%$; B: unstandardized regression weight; S.E.: standard error; Sig.: significance; $\operatorname{Exp}(B)$ : exponentiation of the B coefficient; Wald: Wald chi-square value; Df: the degrees of freedom; -: Factors that did not affect willingness to sell: soil concerns, age, wheat area, corn area, family, employment, and education.

The results showed that the predicted logit of (PERCENTAGE OF WILLINGNESS TO SELL) $=$ $1.827+(-1.034) *$ SELL IT $+(0.620) *$ SOIL CONCERNS $+(-3.535) *$ ANIMALS $+(-0.992) *$ TIME SPENT ON FARM $+(-0.463) *$ AGE OF FARMER $+(0.162) *$ WHEAT AREA $+(-3.316) *$ FARM TYPE $+(0.239) *$ EMPLOYMENT $+(0.024) *$ LEVEL OF EDUCATION $+(3.393) *$ PERCENTAGE OF. CORN + $(-0.165) *$ CORN AREA $+(0.326) *$ FAMILY.

Binary logistic regression (Table 4) showed that farmers who already sell straw and have animals, farmers who have corn, and the percentage of willingness to sell the corn straw were significant predictors of willingness to sell the wheat straw $(p<0.05)$, while engagement in agriculture can be potentially significant $(p<0.1)$. Soil concerns, corn area, wheat area, farm type, employment, education, and number of family members were marginally nonsignificant $(p>0.05)$.

The Impact of Factors on the Willingness to Sell the Straw

(I) Currently, selling wheat straw has a significantly negative $(p<0.05)$ relationship with the percentage (more than $>50 \%$ ) of willingness to sell the straw. Farmers who already are selling straw in the market are willing to sell more than half of it to power plants, while we can see a decrease for the others who do not already have a market, which means that even if they had a market, they would tend to sell less than half of the wheat straw. As a result, there are increases in farms that have a market for selling straw; the odds ratio of percentage of willingness to sell increases by 2.808 $(1 / 0.356)(\beta=-1.034)$ times compared to farmers without a market. The contrasts between market and no market are depicted by the average farmer's willingness (Table 3) to sell more than half of their straw being higher $(0.690 \pm 0.467)$ than without a market $(0.487 \pm 0.501)$.

(II) As for soil concerns, we can see a positive impact on the willingness to sell the straw. Farmers who do not incorporate the straw into the ground tend to sell less than half of the straw; this could be because they use it for other purposes. Those who incorporate it into the soil are $1.859(=\beta 0.620)$ times more likely to sell more than half of the straw if there is a market for straw. This can explain why soil concerns are low and farmers who are not incorporating into the soil are using it for other purposes (feeding animals or selling it). The variation between soil concerns shows that farmers who do not incorporate the straw into the soil are less likely to sell more than half of their straw $(0.503 \pm 0.501)$ compared to those who incorporate it into the soil $(0.758 \pm 0.435)$.

(III) Moreover, animals have a significantly negative impact on the willingness to sell the straw $(p<0.05)$. Farmers who have animals tend to sell less than half of their straw, while those who do not have animals are $34.483(1 / 0.029)(=\beta-3.535)$ times more likely to sell more than half of their straw. 
Farmers who do not have animals are highly likely to sell more than half of the straw $(0.879 \pm 0.323)$, compared to those who have animals $(0.386 \pm 0.489)$.

(IV) Engagement in agriculture (part-time or full-time) tends to have a significant impact $(p<0.1)$ on willingness to sell the straw. However, part-time farmers are $2.695(1 / 0.371)(=\beta-0.992)$ more likely to agree to sell more than half of their straw $(0.556 \pm 0.500)$, compared with full-time farmers $(0.539 \pm 0.500)$.

(V) Age has a negative impact on willingness to sell more than half of the straw: farmers aged $20-40$ years were willing to sell $>50 \%$ of straw for around $1.589(=\beta-0.463)$ times more than older farmers; however, this difference was not significant and so is not considered to shape the willingness to sell straw.

(VI) Land area of wheat has a positive impact on the willingness to sell straw: farmers who have less than 10 hectares tend to sell less than half of the straw, while those who have more than 10 hectares are $1.175(=\beta 0.162)$ times more likely to sell $>50 \%$ of the straw; however, this is not significant. Farmers who have more than 10 hectares have a higher probability of selling more than half of the straw $(0.546 \pm 0.510)$ compared to those who have less than 10 hectares $(0.544 \pm 0.500)$; however, this is a slight difference $(p>0.05)$.

(VII) Farm type has a significantly $(p<0.01)$ negative impact on willingness to sell more than half of the straw; we can see that farmers who have only wheat are willing to sell more than half of their straw, compared with the farmers who have both corn and wheat. Farmers who have only wheat are 27.777 ( $=\beta-3.316)$ times more likely to sell the straw than farmers who have both corn and wheat.

(VIII) Employment is also not significant in terms of willingness to sell the straw; however, farmers whose primary profession is outside of agriculture tend to sell more than half of the straw (1.27 (= $\beta$ 0.239) times more likely than farmers who deal only with agriculture).

(IX) Education: farmers who are educated to university level tend to sell more than $50 \%$ of straw; however, this is not a significant factor shaping willingness.

$(X)$ The willingness of farmers to sell more than half of the corn straw has a significantly positive impact on the willingness to sell the wheat $(p<0.05)$. Farmers who sell less than $50 \%$ of corn straw tend to sell less than $50 \%$ of wheat straw $(0.08+0.360)$. Farmers who sell more than half of the corn straw tend to sell more than half of their wheat straw, too $(0.67+0.482)$; they are 29.748 times $(\beta=3.393)$ more likely to sell it compared to those who sell less than $50 \%$ of corn straw.

(XI) Land area of corn has a negative impact on the willingness to sell the straw: farmers who have more than 10 hectares of corn tend to sell less than half of their straw $(0.47 \pm 0.516)$, while those who have less than 10 hectares are $1.179(=\beta-0.165)$ times more likely to sell more than half of the wheat straw on average $(0.55 \pm 0.498)$; however, this is not significant $(p>0.05)$ and could be because farms with a higher area of corn also have more animals.

(XII) Household size: those farmers with more than 10 family members are more likely to be willing to sell more than half of their straw, compared with the group 2 family size (1-9).

As shown in Table 4 , except for having a market, having animals, farm type $(p<0.05)$, and engagement in agriculture $(p<0.08)$, all other variables do not have an impact on the willingness to sell the wheat straw. It can be statistically justified $(p<0.05)$ that only three variables included in the model have an impact on the willingness to sell the straw. Papers on methodology recommend the use of the so-called $\mathrm{R}$ value to express the role and power of specific independent variables in a model. The size of the value denotes the order of "importance" of independent variables. This index is not a part of the output of the model; it needs to be calculated using the following equation: $R=\sqrt{\frac{\text { Wald }-2 d f}{D o}}$. Willingness to sell the straw is mostly (0.383) shaped by the willingness to sell the corn straw, followed by the presence of animals on the farm (0.306), farm type (0.231), and the partial impact (0.059) of engagement in agriculture and of having a market $(0.083)$. 


\section{Discussion}

The main aspects of the research results are the same as in the international literature, but they still have many local features. Almost half of the farmers are willing to supply a fixed area of straw $(44.2 \%)$ with a spot market price (68\%). Similar results can be found in the study of Glithero et al. [18], where $42 \%$ of farmers chose to supply a fixed area of straw, while the most popular response was fixed price (34\% of farmers). This means that in Kosovo, farmers do not want the risk of losing potential gains when market prices rise. The potential market of straw for bioenergy purposes is new to most farmers, so it is possible that they can expect the price to rise if this industry starts to take off. According to Kurskowa et al. [53], an unstable biomass market and its price fluctuations are seen as a weakness and threat, whereby the poor state of infrastructure and an unfavorable fuel situation can harm the market [54]. The biggest barrier to selling the straw is the lack of a market $(74.1 \%)$ and a lack of machinery $(50.9 \%)$. Around $50.9 \%$ of the farmers sold their straw at the farm gate, and a few farmers did not bale due to the timing of operations or the incorporation of straw. In the study by Glithero et al. [18], the lack of a market and a lack of machinery were excuses given by less than $10 \%$ of the farmers. The main incentives to straw baling are a good price $(75 \%)$ and a guaranteed market $(67.8 \%)$. Regarding the conditions, most farmers (59.4\%) are willing to supply under a contract length for a maximum $10-15$ years with a relatively low price per $15-\mathrm{kg}$ bale of $€ 0.57$, from which the price per ton would be 38 euros; in total, farmers would generate 2,970,038 euros. Different studies use different prices per ton, like 56.48 euros/ton, 32 euros/ton, or 50 euros/ton $[18,40,55]$. Similar results can be seen in Poland [54], where biomass production is mostly dependent on raw material prices and a guaranteed market. Most of the straw is used for bedding $(37.60 \%)$ and feeding animals $(19.39 \%)$; there is a very low amount of straw that is incorporated back into the soil (9.73\%). According to Coperland and Turley [22], straw is used to feed livestock and the roughage can compromise a minimum of $10 \%$ of the feed ration; however, it is impossible to know the exact quantities used because different farmers have different feeding systems and straw bedding depends on livestock production, age, and management practices. Furthermore, different studies state that dry straw has no value as an animal feed, although it can be baled, used as bedding, plowed back into the ground, or burned, causing environmental problems due to the gas release into the atmosphere $[26,56]$. From the results, we can conclude that, in general, farmers are willing to supply more than half of their straw $(64.73 \%)$; similar results were found in the study by Glithero et al. [18]. From the total sample, $45 \%$ of farmers were willing to sell $33.07 \%$ of their straw; these farmers were part of the first group, which was characterized by willingness to sell less than $50 \%$ of the total straw. The second group was characterized by a willingness to sell more than $50 \%$ of the straw; this group contained $55 \%$ of the farmers, with a willingness to sell an average $89.73 \%$ of the straw. In the study by Batidziari et al. [21], $80-85 \%$ of the biomass was available at the farm gate; however, they required a minimum of $2 \mathrm{t} \mathrm{ha}^{-1}$ of residues to reduce soil erosion and additional analysis would allow for a more accurate evaluation of sustainable residue removal rates. By performing a binary logistic regression, we found which variables have a significant impact on willingness to sell more than $50 \%$ of the straw: farmers who are already selling the straw in the market are also willing to sell more than half of the straw for energy purposes, while farmers who are willing to sell less than $50 \%$ for energy purposes currently do not sell the straw at any market. This had a significant impact on overall willingness to sell as the number of farmers who want to sell less than $50 \%$ on the market is high. Farmers who have animals tend to sell less than half of their straw, while farmers who do not have animals are 34.48 times more likely to sell more than half of their straw. Farmers who have only wheat tend to sell more than half of their straw (this could also be linked to the presence of animals); they are 27.7 times more likely to sell than farmers who have both corn and wheat cultures. Selling the corn straw is also linked to wheat straw: farmers who would sell more than $50 \%$ of the corn straw are also willing to sell more than $50 \%$ of the wheat straw; they are 29.75 times more likely to sell it compared to those who sell less than half of the corn straw.

Engagement in agriculture tended to have a significant impact as part-time farmers were 2.69 times more likely to agree to sell more than half of their straw than full-time farmers. A factor that 
was not significant in shaping the willingness to sell more than $50 \%$ of the straw was soil concerns, as farmers who incorporated the straw into the soil were willing to sell more than $50 \%$. This is contrary to the findings of Glithero et al. [18], in which almost half of the farmers who currently incorporated their straw were not willing to bale straw for bioenergy purposes. Then there are other factors such as: land area with wheat, employment, land area with corn, education, and family size. We conclude that farmers' attitudes toward straw removal or incorporation are potentially not well founded, as more than half of farmers are willing to sell almost all of their straw, while the incorporation rate does not meet the sustainable requirements. Hence, incentives towards bioenergy production most be increasingly integrated with sustainability practices if policy makers are to achieve the combined goals of food and energy security. In order to improve straw availability, Batidziari et al. [21] suggest no-till cultivation, improving animal feed conversion efficiency, improving agricultural management systems, and using contractors to collect residues where they are currently burned. We also found a potential supply in the future from modernizing animal farms: the bedding straw could be used for energy purposes, while another option to increase the capacity of biomass energy is planting the perennial energy crop Sida hermaphrodita on marginal soils [57-59], which can also increase and restore its fertility [60]. Grass could be another option as a partial substitute for other biomass [61]. However, the intervention of institutions is necessary in order to push farmers to incorporate part of their straw into the land.

\section{Conclusions}

We have determined what conditions are necessary to avoid burning straw on the field and thereby wasting valuable energy. The results indicate that the specific market price and contractual relationships clearly determine the willingness to sell straw. Therefore, if we want to avoid the practice of burning agricultural residues (straw) in the area under study, we need to have a proper market structure and well-regulated contractual terms. Subtracting the amount of biomass associated with nutrient supply and livestock use from the amount of biomass that can be produced gives information on the amount of potential energy biomass (briquettes, pellets). The most important issues that we clarified during our study are the factors that influence the sale of extra straw among farmers, which is $50-65 \%$ of all straw. Our results have clearly shown that wheat straw's propensity to sell is significantly increased if farmers can identify this product line as a real market segment. This means that the number of active farmers will increase significantly if appropriate sales channels are created in the given market environment. Studies have also shown that livestock farming significantly influences the willingness to sell straw. Naturally, the high market price of straw can have a negative impact on livestock production, and a regulatory environment that does not substantially influence the amount of straw used in livestock farming should be created. Thus, in the examined farming environment, a complex set of objectives is formed, according to which a part of the produced straw must be provided in quantities and at prices that are available for animal husbandry. The environmentally friendly treatment of surplus straw (avoiding burning in the field by all means) should be directed to attractive market conditions. In addition to wheat straw, corn stalk has a significant impact on the market for bioenergy derived from biomass.

Farmers who produce both wheat and corn see the same market opportunities for both by-products. Care should therefore be taken to ensure that the improvement of market opportunities for wheat straw and the positive change in the market conditions for corn stalks do not diminish the supply of livestock straw. It is also clear that small or part-time farmers are much more willing to sell than large farmers or those who work full-time in agriculture. This is presumably due to the lower production risk. The analysis also showed that farmers' decisions are not influenced by soil nutrient supply issues, so at the time of the survey, this would not have influenced their decision to sell straw. This research also demonstrates the need to incorporate sales constraints (state regulators) into the market system in order to avoid overselling straw. An interesting finding is that younger farmers respond flexibly to new sales opportunities, while older farmers prefer to use traditional livestock farming. The survey found 
that level of education does not influence how much a farmer chooses to sell. However, we found that farmers with higher levels of education were more willing to sell over $50 \%$ of their straw, meaning that they would become part of the energy biomass market. We have statistically demonstrated that the three significant factors influencing wheat straw sales need to be examined first in order to understand the relationships affecting willingness to sell. Farmers' production of corn and the by-product thereof increases their willingness to sell straw. In short, if a farmer produces corn in addition to wheat, s/he will sell the wheat straw together with the corn stalks as they are positively correlated. A significant factor when farmers are engaged in animal husbandry is always the amount of straw needed for bedding. The effect on economic size is significant, so if the economy is larger, farmers are willing to sell more straw to the bioenergy market, and a well-functioning market will greatly influence the activity and number of its participants. The study details show that a good market structure that promotes the use of biomass for energy would increase farmers' incomes, reduce emissions from open field burning, and help achieve efficient energy recovery of field waste biomass (wheat straw). Based on the results of the study, it is possible to outline the directions of sustainable biomass energy utilization and development for policy-makers, on the basis of which an efficient subsidy system and market instruments can be developed for the given region. The results of the research are also worth highlighting because most of the countries in southeastern Europe are not yet members of the EU. The regulations related to open field burning vary, and, as in Chinese agricultural practice, may be associated with a significant environmental problem that will also increase GHG emissions in the near future.

Limitations: Our study does not cover all possible topics within the biomass utilisation but is limited to what we consider important in the filed of farmers' attitude. The research does not represent farmers' attitudes to the biomass energy market, but the results identify the dominant tendencies of the market community.

Author Contributions: Conceptualization, investigation, methodology, and formal analysis—P.Y.; resources, writing, and editing-C.G.; conceptualization, review, editing, and supervision-C.F. All authors have read and agreed to the published version of the manuscript.

Funding: This research received no external funding.

Acknowledgments: Preparation of the manuscript and our final article was supported by the Szent István University Climate Change Economics Research Centre and Doctoral School of Management and Business Administration at Szent István University. We wish to acknowledge the municipality of Gjakova, whose employees helped us to make contact with farmers and complete the fieldwork; the same goes for the Jehona wheat mill in Ferizaj.

Conflicts of Interest: The authors declare no conflict of interest.

\section{References}

1. Madár, V.; Bácskai, I.; Dhaundiyal, A.; Tóth, L. Development of biomass-based pyrolisis CHP (R + D). Hung. Agric. Eng. 2018, 17-23. [CrossRef]

2. Böröcz, M.; Sz\Hoke, L.; Horváth, B. Possible climate friendly innovation ways and technical solutions in the agricultural sector for 2030. Hung. Agric. Eng. 2016, 55-59. [CrossRef]

3. Greening Our Energy Supply. The Role of Bioenergy from Forestry and Agriculture. Publications Office, European Union. Available online: https://ec.europa.eu/info/sites/info/files/food-farming-fisheries/ sustainability_and_natural_resources/documents/leaflet-greening-our-energy-supply_en.pdf (accessed on 12 May 2020).

4. Yanli, Y.; Peidong, Z.; Wenlong, Z.; Yongsheng, T.; Yonghong, Z.; Lisheng, W. Quantitative appraisal and potential analysis for primary biomass resources for energy utilization in China. Renew. Sustain. Energy Rev. 2010, 14, 3050-3058. [CrossRef]

5. The Energy Sector in Kosovo. CEE Bankwatch Network, Prague, Czech Republic. Available online: https://bankwatch.org/beyond-coal/the-energy-sector-in-kosovo (accessed on 15 March 2020).

6. Hoxha, B.B.; Sweeney, K.; Kurti, H.; Dulaj, D.; Papa, A. Kosovo Case Study: Lignite Coal—Energy of the Past, Coalbed Methane Extraction-Energy of the Future. In Proceedings of the 26th European Biomass Conference and Exhibition, Copenhagen, Denmark, 14-17 May 2018; pp. 1365-1372. [CrossRef] 
7. Ahmetaj, G.; Ejupi, B.; Gojani, R. The Prospects for an Energy Market in Kosovo-The Case of Electricity. In Sustainable Development; Institute for Development Policy: Prishtinë, Kosovo, 2015; ISBN 978-9951-627-16-0.

8. Dreshaj, A.; Millaku, B.; Shala, S.; Selimaj, A.; Shabani, H. Sources of Air Pollution, Environmental Impacts and Exploitation of Natural Resources in Kosovo. In Proceedings of the CBU International Conference on Innovations in science and education, Prague, Czech Republic, 22-24 March 2017; Volume 5, p. 1275.

9. Horváth, B.; Fogarassy, C. Analysis of Circular Development and Investment Possibilities (Transport, Energy and Building) Related to International Sports Event Planning. YBL J. Built Environ. 2017, 5, 58-72. [CrossRef]

10. Horvath, B.; Mallinguh, E.; Fogarassy, C. Designing Business Solutions for Plastic Waste Management to Enhance Circular Transitions in Kenya. Sustainability 2018, 10, 1664. [CrossRef]

11. Kashif, M.; Awan, M.B.; Nawaz, S.; Amjad, M.; Talib, B.; Farooq, M.; Nizami, A.S.; Rehan, M. Untapped renewable energy potential of crop residues in Pakistan: Challenges and future directions. J. Environ. Manag. 2020, 256, 109924. [CrossRef]

12. Fogarassy, C.; Horvath, B.; Magda, R. Business Model Innovation as a Tool to Establish Corporate Sustainability. Visegr. J. Bioeconomy Sustain. Dev. 2017, 6, 50-58. [CrossRef]

13. Bytyçi, B.; Gjergjizi, H. Farm classification in Kosovo based on agri-economic criteria. In Proceedings of the 50th Croatian \& 10th International Symposium on Agriculture, Opatija, Croatia, 16-20 February 2015; pp. 195-199.

14. Moustakas, K.; Loizidou, M.; Rehan, M.; Nizami, A.S. A review of recent developments in renewable and sustainable energy systems: Key challenges and future perspective. Renew. Sustain. Energy Rev. 2020, 119, 109418. [CrossRef]

15. Gabrielle, B.; Gagnaire, N. Life-cycle assessment of straw use in bio-ethanol production: A case study based on biophysical modelling. Biomass Bioenergy 2008, 32, 431-441. [CrossRef]

16. Daioglou, V.; Stehfest, E.; Wicke, B.; Faaij, A.; Van Vuuren, D.P. Projections of the availability and cost of residues from agriculture and forestry. GCB Bioenergy 2016, 8, 456-470. [CrossRef]

17. Use of Residues from Agriculture and Forestry as Energy Sources Improves Food Security. Available online: https://phys.org/news/2015-12-residues-agriculture-forestry-energy-sources.html (accessed on 22 May 2019).

18. Glithero, N.J.; Ramsden, S.J.; Wilson, P. Barriers and incentives to the production of bioethanol from cereal straw: A farm business perspective. Energy Policy 2013, 59, 161-171. [CrossRef] [PubMed]

19. Swanston, S.; Newton, A. Mixtures of UK wheat as an efficient and environmentally friendly source for bioethanol. J. Ind. Ecol. 2005, 9, 109-126. [CrossRef]

20. Glithero, N.J.; Wilson, P.; Ramsden, S.J. Straw use and availability for second generation biofuels in England. Biomass Bioenergy 2013, 55, 311-321. [CrossRef] [PubMed]

21. Batidzirai, B.; Valk, M.; Wicke, B.; Junginger, M.; Daioglou, V.; Euler, W.; Faaij, A.P.C. Current and future technical, economic and environmental feasibility of maize and wheat residues supply for biomass energy application: Illustrated for South Africa. Biomass Bioenergy 2016, 92, 106-129. [CrossRef]

22. Coperland, J.; Turley, D. National and Regional Supply/Demand Balance for Agricultural Straw in Great Britain; National Non-Food Crops Centre: New York, NY, USA, 2008.

23. Skøtt, T. Straw to Energy: Status, Technologies and Innovation in Denmark 2011; Agro Business Park A/S: Tjele, Denmark, 2011.

24. Silgram, M.; Chambers, B.J. Effects of long-term straw management and fertilizer nitrogen additions on soil nitrogen supply and crop yields at two sites in eastern England. J. Agric. Sci. 2002, 139, 115-127. [CrossRef]

25. Hamdy, Y.A. The current situation of Egyptian agricultural wastes. In Proceedings of the Anaerobic Treatment of Solid Wastes Workshop, Seville, Spain, 13-14 April 1998; Volume 4, pp. 1-5.

26. Palmieri, N.; Forleo, M.B.; Giannoccaro, G.; Suardi, A. Environmental impact of cereal straw management: An on-farm assessment. J. Clean. Prod. 2017, 142, 2950-2964. [CrossRef]

27. Nguyen, T.L.T.; Hermansen, J.E.; Mogensen, L. Environmental performance of crop residues as an energy source for electricity production: The case of wheat straw in Denmark. Appl. Energy 2013, 104, 633-641. [CrossRef]

28. Dees, M.; Elbersen, B.; Fitzgerald, J.; Vis, M.; Anttila, P.; Forsell, N.; Ramirez-Almeyda, J.; García Galindo, D.; Glavonjic, B.; Staritsky, I. A Spatial Data Base on Sustainable Biomass Cost-Supply of Lignocellulosic Biomass in Europe-Methods \& Data Sources; S2BIOM Project Report 1.6; University of Freiburg: Freiburg, Germany, 2017; p. 176. [CrossRef] 
29. Valin, H.; Peters, D.; Berg, M.; van den Frank, S.; Havlík, P.; Forsell, N.; Hamelinck, C. The land use change impact of biofuels consumed in the EU. GLOBIM 2015.

30. Weiser, C.; Zeller, V.; Reinicke, F.; Wagner, B.; Majer, S.; Vetter, A.; Thraen, D. Integrated assessment of sustainable cereal straw potential and different straw-based energy applications in Germany. Appl. Energy 2014, 114, 749-762. [CrossRef]

31. Jinming, B.; Overend, R. Assessment of Biomass Resource Availability in China; China Environmental Science Press: Beijing, China, 1998.

32. Williams, R.H. Variants of a Low CO2-Emitting Energy Supply System (LESS) for the World-Prepared for the IPCC Second Assessment Report Working Group IIa; Pacific Northwest Laboratories: Richland, WA, USA, 1995; Volume 39.

33. Yamamoto, H.; Yamaji, K.; Fujino, J. Evaluation of bioenergy resources with a global land use and energy model formulated with SD technique. Appl. Energy 1999, 63, 101-113. [CrossRef]

34. Angelis-Dimakis, A.; Biberacher, M.; Dominguez, J.; Fiorese, G.; Gadocha, S.; Gnansounou, E.; Guariso, G.; Kartalidis, A.; Panichelli, L.; Pinedo, I.; et al. Methods and tools to evaluate the availability of renewable energy sources. Renew. Sustain. Energy Rev. 2011, 15, 1182-1200. [CrossRef]

35. Lewandowski, I.; Weger, J.; Van Hooijdonk, A.; Havlickova, K.; Van Dam, J.; Faaij, A. The potential biomass for energy production in the Czech Republic. Biomass Bioenergy 2006, 30, 405-421. [CrossRef]

36. Karaj, S.; Rehl, T.; Leis, H.; Müller, J. Analysis of biomass residues potential for electrical energy generation in Albania. Renew. Sustain. Energy Rev. 2010, 14, 493-499. [CrossRef]

37. Said, N.; El-Shatoury, S.A.; Díaz, L.F.; Zamorano, M. Quantitative appraisal of biomass resources and their energy potential in Egypt. Renew. Sustain. Energy Rev. 2013, 24, 84-91. [CrossRef]

38. Scarlat, N.; Martinov, M.; Dallemand, J.-F. Assessment of the availability of agricultural crop residues in the European Union: Potential and limitations for bioenergy use. Waste Manag. 2010, 30, 1889-1897. [CrossRef] [PubMed]

39. Monforti, F.; Bódis, K.; Scarlat, N.; Dallemand, J.-F. The possible contribution of agricultural crop residues to renewable energy targets in Europe: A spatially explicit study. Renew. Sustain. Energy Rev. 2013, 19, 666-677. [CrossRef]

40. Marks-Bielska, R.; Bielski, S.; Novikova, A.; Romaneckas, K. Straw Stocks as a Source of Renewable Energy. A Case Study of a District in Poland. Sustainability 2019, 11, 4714. [CrossRef]

41. Zhang, F.; Li, C.; Yu, Y.; Johnson, D.M. Resources and Future Availability of Agricultural Biomass for Energy Use in Beijing. Energies 2019, 12, 1828. [CrossRef]

42. Chinnici, G.; D’Amico, M.; Rizzo, M.; Pecorino, B. Analysis of biomass availability for energy use in Sicily. Renew. Sustain. Energy Rev. 2015, 52, 1025-1030. [CrossRef]

43. Cai, J.; Liu, R.; Deng, C. An assessment of biomass resources availability in Shanghai: 2005 analysis. Renew. Sustain. Energy Rev. 2008, 12, 1997-2004. [CrossRef]

44. Giannoccaro, G. Survey data of stated farmer's preferences and willingness to supply straw. Data Brief 2017, 11, 12-14. [CrossRef] [PubMed]

45. Digruber, T.; Sass, L.; Cseri, A.; Paul, K.; Nagy, A.V.; Remenyik, J.; Molnár, I.; Vass, I.; Toldi, O.; Gyuricza, C. Stimulation of energy willow biomass with triacontanol and seaweed extract. Ind. Crops Prod. 2018, 120, 104-112. [CrossRef]

46. Fogarassy, C.; Toth, L.; Czikkely, M.; Finger, D.C. Improving the Efficiency of Pyrolysis and Increasing the Quality of Gas Production through Optimization of Prototype Systems. Resources 2019, 8, 182. [CrossRef]

47. Czikkely, M.; Hoang, N.H.; Fogarassy, C. CIRCULAR TRANSFORMATION OF CURRENT BUSINESS SOLUTIONS IN WASTEWATER MANAGEMENT. Pol. J. Manag. Stud. 2019, 20, 196-209. [CrossRef]

48. Gaus, C.-C.; Menrad, K.; Decker, T. Farmers' willingness to sell straw in Bavaria. In Proceedings of the 53rd Annual Conference, Berlin, Germany, 25-27 September 2013; German Association of Agricultural Economists (GEWISOLA): Berlin, Germany, 2013.

49. Latifi-Pupovci, H.; Selmonaj, M.; Ahmetaj-Shala, B.; Dushi, M.; Grajqevci, V. Incidence of haematological malignancies in Kosovo-A post "uranium war" concern. PLoS ONE 2020, 15, e0232063. [CrossRef]

50. Park, H.A. An introduction to logistic regression: From basic concepts to interpretation with particular attention to nursing domain. J. Korean Acad. Nurs. 2013, 43, 154-164. [CrossRef]

51. Muriqi, S.; Fekete-Farkas, M.; Baranyai, Z. Drivers of Cooperation Activity in Kosovo's Agriculture. Agriculture 2019, 9, 96. [CrossRef] 
52. Morissette, R.; Savoie, P.; Villeneuve, J. Corn Stover and Wheat Straw Combustion in a 176-kW Boiler Adapted for Round Bales. Energies 2013, 6, 5760-5774. [CrossRef]

53. Kurowska, K.; Kryszk, H.; Bielski, S. Determinants of biomass production for energy purposes in North-Eastern Poland. In Proceedings of the International Conference Engineering for Rural Development, Jelgava, Latvia, 29-30 May 2014; pp. 417-422.

54. Brodziński, Z.; Kryszk, H.; Kurowska, K. Market of Producers and Processors of Agricultural Biomass for Energy Purposes. Pol. J. Environ. Stud. 2014, 23, 619-627.

55. Elbersen, B.; Startisky, I.; Naeff, H.; Hengeveld, G.; Schelhaas, M.J.; Böttcher, H. Spatially Detailed and Quantified Overview of EU Biomass Potential Taking into Account the Main Criteria Determining Biomass Availability from Different Sources; Intelligent Energy Europe: Brussels, Belgium, 2012.

56. Cascone, S.; Rapisarda, R.; Cascone, D. Physical Properties of Straw Bales as a Construction Material: A Review. Sustainability 2019, 11, 3388. [CrossRef]

57. Jablonowski, N.D.; Kollman, T.; Nabel, M.; Damm, T.; Klose, H.; Muller, M.; Blasing, M.; Seebold, S.; Krafft, S.; Kuperjans, I.; et al. Valorization of Sida (Sida hermaphrodita) biomass for multiple energy purposes. Gcb Bioenergy 2017, 9. [CrossRef]

58. Nabel, M.; Temperton, V.M.; Poorter, H.; Lücke, A.; Jablonowski, N.D. Energizing marginal soils-The establishment of the energy crop Sida hermaphrodita as dependent on digestate fertilization, NPK, and legume intercropping. Biomass Bioenergy 2016, 87, 9-16. [CrossRef]

59. Nabel, M.; Temperton, V.; Poorter, H.; Jablonowski, N.D. Energy Crop (Sida Hermaphrodita) Fertilization Using Digestate and Legume Intercropping under Marginal Soil Conditions. In Proceedings of the The European Biomass Conference and Exhibition, Wien, Austria, 1-4 June 2015.

60. Nabel, M.; Schrey, S.; Temperton, V.; Koller, R.; Schurr, U.; Jablonowski, N.D. The Importance of Organic Fertilisation and Perennial Crops for Land Degradation Neutrality. In Proceedings of the Tropentag, Bonn, Germany, 20-22 September 2017.

61. Mattioli, A.; Boscaro, D.; Dalla Venezia, F.; Correale Santacroce, F.; Pezzuolo, A.; Sartori, L.; Bolzonella, D. Biogas from Residual Grass: A Territorial Approach for Sustainable Bioenergy Production. Waste Biomass Valor 2017, 8, 2747-2756. [CrossRef] 